\title{
Do elections matter for private-sector healthcare management in Brazil? An analysis of municipal health policy
}

\author{
Alecia J. McGregor ${ }^{1 *}$ D, Carlos Eduardo Siqueira ${ }^{2}$, Alan M. Zaslavsky ${ }^{3}$ and Robert J. Blendon ${ }^{4}$
}

\begin{abstract}
Background: This study analyzed several political determinants of increased private-sector management in Brazilian health care. In Brazil, the poor depend almost exclusively on the public Unified Health System (the SUS), which remains severely underfunded. Given the overhead costs associated with privately contracted health services, increased private management is one driver of higher expenditures in the system. Although left parties campaign most vocally in support of greater public control of the SUS, the extent to which their stated positions translate into health care policy remains untested.

Methods: Drawing on multiple publicly available data sources, we used linear regression to analyze how political partyin-power and existing private sector health care contracting affect the share of privately managed health care services and outsourcing in municipalities. Data from two election periods - 2004 to 2008 and 2008 to 2012-were analyzed.

Results: Our findings showed that although private sector contracting varies greatly across municipalities, this variation is not systematically associated with political party in power. This suggests that electoral politics plays a relatively minor role in municipal-level health care administration. Existing levels of private sector management appear to have a greater effect on the public-private makeup of the Brazilian healthcare system, suggesting a strong role of path dependence in the evolution of Brazilian health care delivery.

Conclusion: Despite campaign rhetoric asserting distinct positions on privatization in the SUS, factors other than political party in power have a greater effect on private-sector health system management at the municipal-level in Brazil. Given the limited effect of elections on this issue, strengthening participatory bodies such as municipal health councils may better enfranchise citizens in the fundamental debate over public and private roles in the health care sector.
\end{abstract}

Keywords: Health systems, Brazil, Unified health system, Sus, Private contracting, Neoliberalism, Political parties

\section{Background}

In Brazil, grievances about mismanagement and lack of quality in health care provision exploded in mass protests in 2013. A vocal left argued that the proliferation of private sector stakeholders alongside public sector provision was driving up overhead costs and complicating the structure of Brazilian healthcare delivery. However, the role of elected officials in driving or slowing this phenomenon is unclear.

\footnotetext{
* Correspondence: alecia.mcgregor@tufts.edu

'Department of Community Health, Tufts University, 574 Boston Ave, Suite

208, Medford, MA 02155, USA

Full list of author information is available at the end of the article
}

This study examined whether and how political party in power influences public-private contracts in health care delivery in Brazil. We compared whether municipal election results, or existing health system characteristics, played a greater role in determining the extent of private sector involvement in health care provision. While previous literature has examined local determinants of health system composition, and the overall distribution of health care contracts in Brazil, no existing studies, to our knowledge, analyze the effect of partisanship on health care privatization in Latin America's largest country and biggest economy [1-7]. Brazil's health system is a decentralized, two- part public-private system that grants access to care to the poor and the wealthy 
through two parallel yet partially overlapping tracks. It does this through a network of public facilities that provide access to care to all Brazilians free of cost, and a parallel private system of operators that limit access to care primarily to those who hold supplementary private health plans or can afford to pay out of pocket. There is some overlap, as individuals with private plans are also entitled to use public facilities, and public-only patients may use a limited number of providers that contract with the government system. Against this backdrop, greater evidence is needed on the political determinants of decisions that may shift or further entrench this divided system. To what extent do electoral politics play a role in strengthening or weakening private health care management in Brazil? This study provides evidence on whether elections truly matter for private-sector health care contracting in Brazil.

\section{Challenges facing the Brazilian health system}

The Unified Health System (Sistema Único de Saúde, or SUS) is simultaneously a source of pride and concern for Brazilians. The SUS boasts a wide network of clinics, health posts, and programs that grant universal access to an array of care free of cost, at the point of service. Despite the broad accessibility of the SUS, widespread reports of poor quality, government underinvestment and mismanagement of funds persist [8]. A majority of Brazilians (77\%) are dissatisfied with the quality of hospital care in the country [9].

Alongside a struggling public system, private ownership and management has increased in health care facilities and in the health care equipment and technology sector [10]. Between 2006 and 2012, the total quantity of privately managed and maintained equipment in the SUS nationwide increased by approximately $88 \%$, while publicly managed equipment grew by only about $51 \%$ [11]. In the decentralized configuration of the SUS, municipal governments have substantial latitude in financial and administrative decisions, and can decide to initiate and maintain contracts with the private sector in health care delivery and administration $[5,12,13]$.

At every level of government, political parties and civic groups voice opposition to the expansion of private health care management. These include left parties such as the Socialism and Freedom Party (PSOL) and until recently, the majority of the Worker's Party (PT), as well as civil society organizations such as the Frente Nacional Contra a Privatização da Saúde (National Front Against the Privatization of Health). These groups contend that increased private-sector contracting privileges a few stakeholders and distorts the intended public nature of the SUS, on which poorer Brazilians are dependent. Yet, it remains unclear whether political parties have staked out distinct positions on the public-private composition of the SUS. Further, it is unclear whether administrative choices at the local level reflect party ideology, or respond to local supply and demand factors.

\section{History of private sector participation in the SUS}

The extant public-private composition of Brazilian health system is rooted in the political history of the country. The "sanitarista" movement-a national political movement driven by public health professional$\mathrm{s}$-pushed to include an ambitious universal health care provision in the 1988 Constitution. As a result, Article 196 of the Constitution defines access to health care as a right that the state must provide. The government created the SUS in 1990 to carry out this duty [10].

The current configuration of the SUS was also shaped by the health care system that preceded it. The SUS replaced the health insurance scheme established in the 1960s by the military dictatorship, which financed individual health care provision through the social security system. This system, the INAMPS (Instituto Nacional de Assistência Médica da Previdência Social), only covered workers employed in the formal sector. Under INAMPS, Brazil witnessed the proliferation of private hospitals, which contracted with the government [14]. This was in part due to a policy in the 1970s that subsidized their construction. By 1989, private hospitals accounted for about $80 \%$ of all hospitals $[15,16]$.

Over the last two decades, a growing number of middle- and upper class Brazilians have purchased private insurance, either individually or through their employers. Between 2003 and 2012, the number of Brazilians holding private plans increased 53\%, from 32 to 49 million [17]. As a result, over $25 \%$ of the Brazilian population also has access to exclusively private sector health care services paid for by a private insurer. Moreover, the Brazilian government also offers a federal tax incentive exempting all private out of pocket health care expenses from taxation. This tax subsidy serves, in practice, to promote private health expenditures and to shift higher income earners, who stand to gain most from the tax break, from the public to the private sector. As a result, the increase in access to private sector care is a middle- to upper- middle class phenomenon. The poor in Brazil continue to depend almost exclusively on public facilities in the SUS for care. ${ }^{1}$

In addition to the private health care that is exclusive to holders of private plans, an array of private companies are involved along different points of the delivery of publicly financed care. Privately managed health care facilities and equipment also play a growing role in publicly-funded care. Between 2006 and 2010, the number of public outpatient facilities in Brazil plateaued, while private facilities continued to grow [10]. The faster growth of private facilities is noteworthy because 
although the majority of SUS-financed inpatient care takes place in private hospitals, most private, for-profit outpatient clinics are for exclusive use of private plan holders [12]. Due to geographic socioeconomic inequalities in Brazil, the need for public facilities is greater in rural areas and in the Northeast region, where the proportion of individuals holding private plans is much lower [18].

A similar trend in private ownership and management took place with medical equipment, ranging from mammogram screening tools to dental equipment [19]. The coexistence of public and private ownership and management of medical equipment in Brazilian health care delivery is widespread (Figure 1). However, the drivers of the growth and local level variation in government procurement of privately managed health care services is less understood. ${ }^{2}$

\section{Politics of the privatization debate}

The viewpoint that nations should shift the provision of publicly-provided services to the private sector is central to the economic philosophy of neoliberalism [20, 21]. Neoliberal reforms became commonplace in Latin American countries in the 1980s under the influence of the World Bank and the International Monetary Fund (IMF) [22-24]. As a proposed solution to high levels of national debt and a dire need for infrastructure, multilateral lenders following the Washington Consensus believed that relegating public services to private companies, which vie for government contracts, would introduce greater competition, efficiency and quality in public service provision [4, 22, 24-27]. The role of IMF and World Bank structural adjustment programs in economic development and fiscal stabilization remains contentious and,whether politicians align themselves with a neoliberal agenda, or support a strong role of the state is politicized in many domestic policy domains. In Brazil, where public participation in the allocation of government resources was a key demand of the social movements that created the SUS, the debate over whether health policy reforms are too strongly influenced by outside actors and neoliberal ideology polarizes the left and right.

Brazil stands out among Latin American countries for adopting a rights-based public health system at the end of the military dictatorship in 1988, but debates continue over whether political leaders prefer privatization reforms in everyday health care management and delivery. The political left voices a fierce desire to guard the public nature of the system, and proponents lean on the Brazilian Constitution for support [28]. Despite the historically entrenched network of private hospitals left over from the military regime, the 1988 Constitution contains provisions to guarantee a health care system that is largely public in nature. Article 196 of the Brazilian Constitution asserts that the provision of health care is the duty of the state, and Article 199 specifies that for-profit, private sector companies should not receive public funds from the SUS [10, 29]. Further, Article 199 declares that the private sector should remain "complementary" to the SUS. However, the issue has become more nuanced in recent years, with the

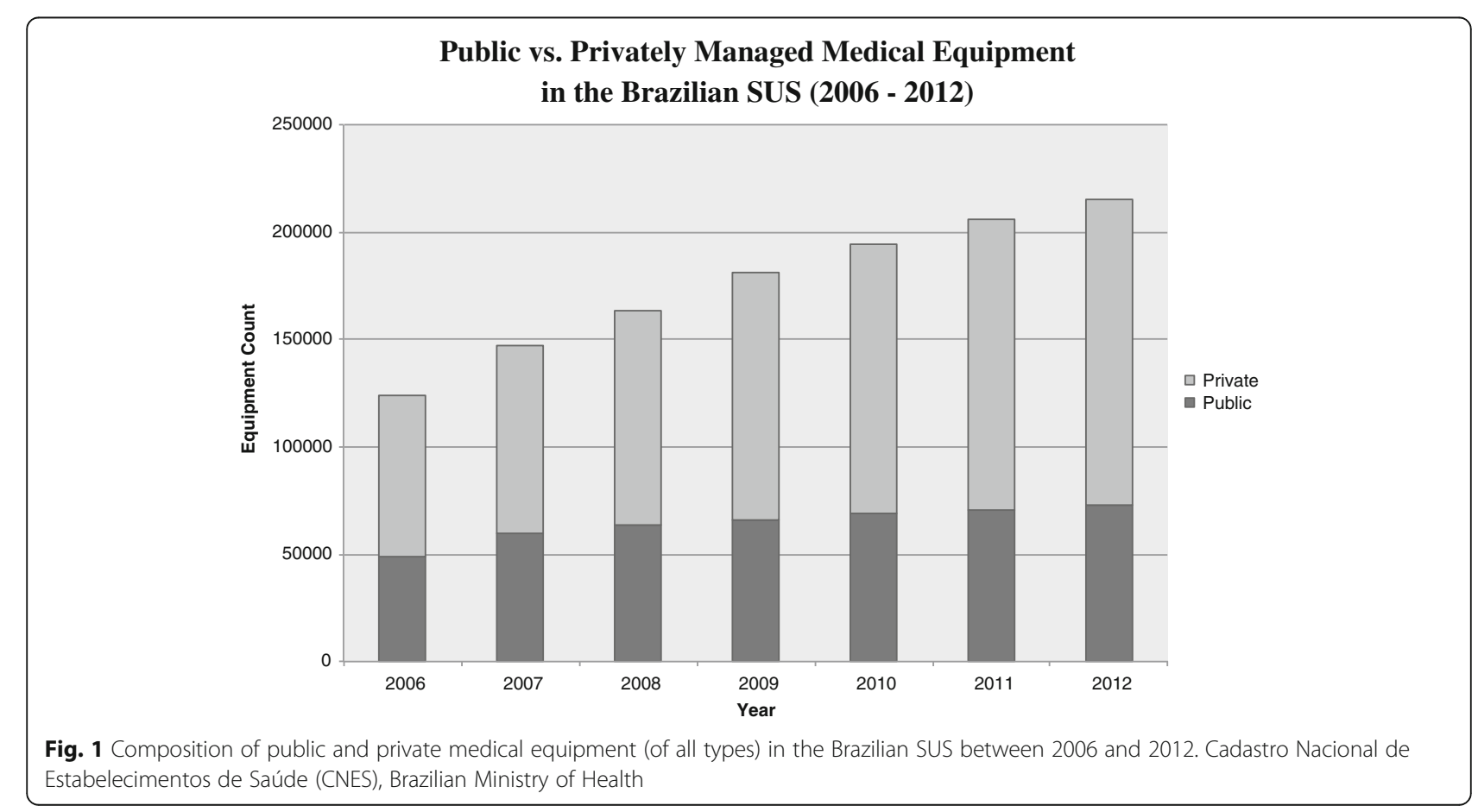


debate on private management contracts (or contratos de gestão) within the SUS [30].

The reliance on private sector entities-both for-profit and non-profit-to carry out administrative and technological functions within the health system is a point of disagreement among actors on the left. Although liberal supporters of private sector contracting often argue that involving the private sector can increase the quality and efficiency of health delivery, this view faces several counterarguments [31]. Arguments against private contracting contend that contracts make the SUS more fragmented, with many competing points-of-view operating in the same system, and that it decreases public control of the SUS's public funds. Private sector health spending has also been shown to extract greater expenditures due to increased overhead costs and a tendency toward overutilization [32]. Though left parties in Brazil campaign against neoliberal policy positions, it is unlcear whether they distinctly avoid contracting with private companies in health care provision.

\section{Political parties in Brazil}

There are more than 30 political parties registered in Brazil's multiparty, federalist system, and parties frequently govern in coalition [33]. However, literature is inconclusive on the extent to which party discipline and cohesive policy behavior are evident among politicians belonging to the same political party. One strand of the literature contends that clientelism - the distribution of goods in exchange for electoral support-drives the behavior of Brazilian political elites and undermines the strength of political parties [34-36]. This strand argues that parties lack the distinctions in ideology or party discipline to send coherent messages on policy positions to the electorate [37-39].

A competing view argues that political parties have become stronger over the years [40]. By this argument, politicians invest in "creating value for the party brands" as a means of distinguishing themselves programmatically from other parties [40]. This party-oriented shift became more viable after larger scale policy reforms rendered small-scale forms of patronage less valuable for politicians. For example, the long-term electoral rewards that parties receive from providing a widely successful social services-"Bolsa Família" (Family Income Support) for example- is more valuable to the party brand than small acts of patronage. This paper leans on the latter strand of the literature and takes the hypothesis that there is an association between poltical party and health policy decisions.

Although disagreement exists on whether Brazilian parties behave ideologically, Brazilian parties self-identify along a left-right ideological spectrum [3, 37, 41-43]. Because of the uncertainty around party adherence to ideological placements, we do not categorize parties based strictly on ideology in the statistical model. However, understanding where political parties lie on this spectrum is important for contextualizing study findings.

\section{Methods}

We approached the study design with two competing hypotheses in mind. First, we hypothesized that left-ofcenter political parties will demonstrate greater support for public sector health services, and thus be associated with fewer contracted private sector health care services. We based this hypothesis on recent theories that contend that Brazilian political parties increasingly demonstrate greater cohesion and programmatic behavior $[2,40]$. The alternative hypothesis held that baseline institutional arrangements-the existing level of publicprivate health care contracts-would be a more important determinant of public-private health care management contracts at the end of a mayoral administration. The second hypothesis relied on theories of path dependence. Although municipal administrations have the power to reexamine and change contracts annually, existing policy arrangements, and the powerful interests that arise from them, may "lock-in" a status quo from which it is politically difficult to depart [44, 45].

To test these hypotheses, we analyzed the publicprivate composition of healthcare services at the end of mayoral administrations. We aimed to estimate whether ideologically distinct political parties behave differently in the domain of private sector contracting in health care, and if not, which factors appear to drive differences in private health care administration in Brazil.

\section{Model building process}

This study used linear regression to analyze the effect of political party in power and other municipal-level determinants on the level of private sector involvement in the Brazilian SUS. Using data from the 2004 and 2008 election cycles, we constructed models to predict the share of private management of health equipment, health care outsourcing and health spending that exists at the end of a mayoral term.

\section{Measures of private-sector healthcare administration}

We chose five dependent variables to measure the degree of private sector contracting and administration in health care. First, we selected three widely used types of medical equipment-dental equipment, ultrasounds, and $\mathrm{x}$-rays-and identified the proportion of these equipment that were privately owned, managed and maintained. The majority of Brazilian municipal health systems have ultrasounds, $x$-rays, and dental equipment whereas less equitably distributed medical equipment (such as Magnetic Resonance Imaging machines or 
MRIs) do not exist in resource poor municipalities. ${ }^{3}$ Overall, very profitable equipment types (such as imaging services) that are densely concentrated in a few wealthy municipalities, tend to be reimbursed above cost by the SUS, and would likely be particularly sensitive to private sector contracts regardless of existing local supply [46].

The percentage of private hospital beds, out of total hospital beds, is included as a measure of private sector dominance of hospital care. We obtained data on private medical equipment and hospital beds from the Cadastro Nacional de Estabelecimentos de Saúde (CNES), or National Registry of Health Establishments, maintained by the Brazilian Ministry of Health [11].

The fifth outcome variable measured the proportion of health care expenditures allocated to outsourced service corporations. We calculated this value for all municipalities in the baseline years 2004 and 2008 and the end of mayoral terms, in 2008 and 2012. We used data from the Sistema de Informações Sobre Orçamentos Públicos em Saúde (SIOPS), or Information System on Public Health Budgets database, provided by the Ministry of Health [47].

Finally, we included a sixth model to estimate health care expenditures per capita to compare whether political party support for privatization and for health care expenditures overall. To maintain comparability of outcomes, we expressed health care expenditures as a percentage of average health expenditures, across municipalities.

\section{Key explanatory variables}

Our primary key predictor is Political Party in Power, which is defined as the party of the mayor elected in 2004 and 2008. The mayor's party plays an important role in choosing the municipality's Secretary of Health (either of the mayor's party or of a coalition party), who oversees the administration and management of the local health care system. Our analysis included the top ten political parties as determined by nationwide representation. Limiting the analysis to 10 of the over 30 Brazilian parties left a substantial sample, as these parties were elected to mayor in over 4600 (close to $85 \%$ of) municipalities in 2004, governing about $83 \%$ of the national population. Their reach in municipal power grew in 2008 , as mayors from these parties were elected in 5176 municipalities, accounting for approximately $93 \%$ of the Brazilian population (using 2010 population numbers) [33]. This growth in municipal power was, in part, due to the merger of two conservative political parties (Party of the Reconstruction of the National Order, or PRONA and the Liberal Party, or $\mathrm{PL}$ ) into the Party of the Republic (PR) party, as well as the increased election of the PT and Brazilian Labor Party (PTB) at the municipal level. As shown in Figs. 2 and 3 , incumbent parties held onto a sizable proportion of mayoral seats across elections (31\% in 2004 and $40 \%$ in 2008). To account for the potential effect of incumbency on local health care privatization, we included a covariate for Incumbency in the model. We retrieved elections data from the Tribunal Superior

\begin{tabular}{|c|c|c|c|c|c|c|c|c|c|c|c|c|}
\hline \multicolumn{13}{|c|}{ Party Elected to Mayor in 2004} \\
\hline \multirow{12}{*}{ 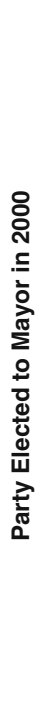 } & & DEM & PDT & PMDB & PP & PPS & PR & PSB & PSDB & PT & PTB & Total \\
\hline & DEM & 314 & 39 & 135 & 64 & 39 & 79 & 27 & 104 & 57 & 63 & 921 \\
\hline & PDT & 25 & 71 & 45 & 30 & 15 & 11 & 4 & 23 & 19 & 16 & 259 \\
\hline & PMDB & 123 & 60 & 370 & 114 & 54 & 76 & 25 & 154 & 70 & 81 & 1127 \\
\hline & PP & 54 & 37 & 102 & 162 & 23 & 33 & 20 & 56 & 36 & 35 & 558 \\
\hline & PPS & 21 & 7 & 27 & 16 & 34 & 10 & 4 & 15 & 11 & 6 & 151 \\
\hline & PR & 30 & 4 & 25 & 12 & 8 & 41 & 12 & 32 & 9 & 17 & 190 \\
\hline & PSB & 11 & 10 & 21 & 3 & 5 & 1 & 29 & 14 & 7 & 12 & 113 \\
\hline & PSDB & 68 & 30 & 155 & 51 & 52 & 55 & 28 & 287 & 73 & 65 & 864 \\
\hline & PT & 15 & 4 & 17 & 10 & 7 & 4 & 1 & 27 & 82 & 3 & 170 \\
\hline & PTB & 47 & 24 & 52 & 37 & 11 & 29 & 5 & 42 & 20 & 68 & 335 \\
\hline & Total & 708 & 286 & 949 & 499 & 248 & 339 & 155 & 754 & 384 & 366 & 4688 \\
\hline
\end{tabular}

Fig. 2 Summary of Party Transitions for Mayoral Seats from 2000 to 2004. Only the top 10 political parties represented in Brazilian municipalities are included. Tribunal Superior Eleitoral (TSE) 


\begin{tabular}{|c|c|c|c|c|c|c|c|c|c|c|c|c|}
\hline \multicolumn{13}{|c|}{ Party Elected to Mayor in 2008} \\
\hline \multirow{12}{*}{ 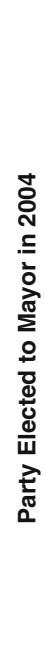 } & & DEM & PDT & PMDB & PP & PPS & PR & PSB & PSDB & PT & PTB & Total \\
\hline & DEM & 222 & 37 & 128 & 37 & 11 & 57 & 43 & 74 & 53 & 46 & 708 \\
\hline & PDT & 15 & 105 & 51 & 38 & 3 & 12 & 9 & 24 & 18 & 11 & 286 \\
\hline & PMDB & 66 & 43 & 443 & 86 & 18 & 45 & 38 & 92 & 64 & 54 & 949 \\
\hline & PP & 24 & 23 & 117 & 207 & $\overline{6}$ & 18 & 20 & 38 & 29 & 17 & 499 \\
\hline & PPS & 12 & 16 & 51 & 16 & 37 & 28 & 28 & 30 & 16 & 14 & 248 \\
\hline & PR & 24 & 17 & 61 & 16 & 6 & 106 & 11 & 43 & 29 & 26 & 339 \\
\hline & PSB & 7 & 5 & 23 & 11 & 2 & 6 & 78 & 7 & 6 & 10 & 155 \\
\hline & PSDB & 43 & 21 & 128 & 32 & 14 & 49 & 29 & 328 & 65 & 45 & 754 \\
\hline & $\begin{array}{l}\text { PT } \\
\end{array}$ & 16 & 17 & 36 & 18 & 5 & 12 & 11 & 34 & 224 & 11 & 384 \\
\hline & $\begin{array}{l}\text { PTB } \\
\end{array}$ & 25 & 24 & 53 & 23 & 14 & 13 & 20 & 40 & 14 & 140 & 366 \\
\hline & Total & 454 & 308 & 1091 & 484 & 116 & 346 & 287 & 710 & 518 & 374 & 4688 \\
\hline
\end{tabular}

Fig. 3 Summary of Party Transitions for Mayoral Seats from 2004 to 2008. Only the top 10 political parties represented in Brazilian municipalities are included. Tribunal Superior Eleitoral (TSE)

Eleitoral (TSE), the Supreme Electoral Court, which maintains a public database on local and national elections in Brazil [48].

As a secondary key predictor, we included Baseline Level of Private-Sector Involvement for each of five response variables to account for the public-private contracting arrangement that existed before each election period. We included the baseline (2004 and 2008) measures for the three equipment types, hospital beds and outsourcing, to test our second hypothesis, that the existing saturation of private sector healthcare contracting reflects a stakeholder environment where the continuation of such agreements is politically difficult to disrupt.

\section{Covariates}

We included additional covariates to analyze the effect of the existing supply of health care equipment and other factors that may generate a demand for private care in a municipality. For models estimating privatization in medical equipment and hospital beds, we included measures for total existing supply (per capita) of the given type of equipment. We incorporated this measure to capture any existing deficit in health care equipment that may have existed at baseline in a municipality. A deficit in health equipment could create a demand for an urgent solution from government, which may include contracting the technology and its maintenance from the private sector.

The model also controlled for the Human Development Index (HDI) to account for the fact that more advanced specialist and tertiary care options are in greater supply in more developed, urbanized areas [3]. Last, we controlled for salary for the top of 4th quintile of income earners in each municipality. This variable provides a measure of the economic standing of the upper middle-class individuals by municipality, and is a proxy for the proportion of municipal residents who hold private health plans. The proportion of private health plans could also drive the level of privately managed and provided health care services that are available.

Using this general model, we conducted linear regression analyses for each of the six outcome variables of interest. We input values at the end of each mayoral term for response variables, and for explanatory variables we used baseline measures from election years. For socio-demographic data, such as population, HDI, and upper middle class income, we used the most recently released data from the 2010 Brazilian Census. Because the Brazilian census is decennial, we used sociodemographic data from 2010, which is the nearest year to the mayoral terms we analyzed. We deleted cases based on availability of data.

\section{Results}

\section{Descriptive statistics}

In aggregate, there was an increase in privately managed equipment of all types between 2006 and 2012 in Brazil (Figure 1). Of all the domains studied, the relative share of privately managed dental equipment increased most substantially (by more than $5 \%$ ) over that time period (Table 1). Two of the five dimensions-ultrasounds and 
Table 1 Average \%Private Sector Involvement in Health Care and Health Care Spending by Year $a, b, c$

\begin{tabular}{|c|c|c|c|c|c|c|}
\hline \multirow[t]{2}{*}{ Year } & \multicolumn{4}{|l|}{ Equipment } & \multirow{2}{*}{$\begin{array}{l}\text { Outsourcing } \\
\text { (\% health expenditures) }\end{array}$} & \multirow{2}{*}{$\begin{array}{l}\text { Health Spending } \\
\text { per capita } \\
\text { (2012\$R) }\end{array}$} \\
\hline & $\begin{array}{l}\text { Dental } \\
\text { (\% Private) }\end{array}$ & $\begin{array}{l}\text { X-Rays } \\
\text { (\% Private) }\end{array}$ & $\begin{array}{l}\text { Ultrasounds } \\
\text { (\% Private) }\end{array}$ & $\begin{array}{l}\text { Hosp. Beds } \\
\text { (\% Private) }\end{array}$ & & \\
\hline \multirow[t]{2}{*}{2008} & 12.3 & 34.8 & 35.8 & 21.9 & 14.5 & 312.4 \\
\hline & $(19.4)$ & $(68.4)$ & $(72.7)$ & (36.6) & (12.9) & (155.4) \\
\hline \multirow[t]{2}{*}{2012} & 17.5 & 35.4 & 34.7 & 18.4 & 16.4 & 540.0 \\
\hline & (33.3) & $(69.7)$ & $(71.4)$ & (21.6) & $(15.2)$ & $(260.3)$ \\
\hline Change & 5.2 & 0.6 & -1.1 & -3.5 & 1.9 & +227.6 \\
\hline
\end{tabular}

${ }^{\mathrm{a}}$ Data are presented as means (interquartile range)

$\mathrm{b}_{\%}$ Private denotes percent privately managed and maintained

'Data Source: National Registry of Health Establishments and Information System on Public Health Budgets, Ministério da Saúde, Brasil

hospital beds-showed an overall decrease in average percentage of municipal-level private sector management across the two periods. The decrease in percent private hospital beds was expected given that there has been a steady increase in public beds since the advent of the SUS [10]. The reduction in the number of private hospitals contracting with the SUS made an increased proportion of public beds possible [10]. Table 1 suggests that contracting of private dental equipment may be driving the aggregate increase in privately managed equipment in the SUS. ${ }^{4}$

For some domains, overall private sector management changed only slightly over the two election periods, but the variation across municipalities was remarkable. For example, privately managed $\mathrm{x}$-rays and ultrasounds remained at about $35 \%$ for both election periods, and changed by only $0.6 \%$ and $-1.1 \%$ respectively. However, the interquartile ranges for private management of both types of equipment were quite large at $69.7 \%$ and $71.4 \%$, respectively. This reflects that in some municipalities, equipment types are entirely privately managed, and in others they are completely public. The regression analysis that follows sought to explain some of the determinants of this variation.

\section{Regression analysis}

Overall, we found that political party-in-power did not have a consistent effect on the proportion of privately managed health care services in a municipality. This is contrary to our hypothesis that Brazilian parties behave programmatically in policy making, but it supports earlier theories on the lack of ideologically consistent policy positions by Brazilian political parties. However, regression analyses upheld our second hypothesis that existing public-private arrangements were more strongly associated with the level of private sector health care contracting at the end of a mayor's administration. Tables 2, 3, 4 and 5 depict the results of a series of linear regression analyses for both election periods.

We found very few significant relationships between political party in office and private sector involvement in health care. However, the most significant findings for parties entering in 2008 were among the Party of Brazilian Social Democracy (PSDB) and the Worker's Party (PT). As shown in Table 2, PSDB in power was significantly associated with fewer privately managed medical equipment (1.7\% fewer $\mathrm{x}$-rays and $2.1 \%$ fewer ultrasounds than the average across all political parties). Interestingly, the association between the PT-the left party with the most political power in Brazilian government-and health care privatization was greater than other parties with respect to ultrasounds and outsourcing. The association with the PT and ultrasounds has a relatively large deviation $(+3.5 \%)$ from the average in the direction of more privatization. The association between the PT and health care outsourcing is $1.21 \%$ greater than the average across all parties studied. These findings are somewhat striking, as the PSDB is generally known to be more supportive of neoliberal policies, while the PT postures as a staunch defender of the public sector in health care [49]. ${ }^{5}$

The effect of party elected in 2004 on 2008 levels of private sector involvement in health care is even less clear (Table 4). No single party is associated with significant privatization outcomes on more than one domain. The conservative Democratas (DEM) party comes closest to an association across multiple domains with higher than average levels of privatization in both $\mathrm{x}$-rays (2\%) and ultrasounds (2.6\%). However, for both outcomes, this association is only significant at the $p<.10$ level. With other strong associations found on only single dimensions, it is difficult to make an interpretation of a party demonstrating a stance on health care privatization during this term.

Incumbency-which is widespread in Brazilian municipal elections (Figs. 2 and 3)-did not have a significant effect on most of the health policy outcomes. However, for private hospital beds (especially in the 2008 election), incumbency does have a strong and statistically significant effect. The strong negative association between incumbency and proportion of private hospital beds suggests that political administrations may offer greater 
Table 2 Party-in-power estimates of linear regressions predicting 2012 level of privatization and health care expenditures by party elected in 2008 (controlling for incumbency, baseline privatization, HDI, and upper middle-class income) ${ }^{a}$

\begin{tabular}{lllllll}
\hline Party Elected In 2008 & Dental & X-rays & Ultrasounds & Hospital Beds & Outsourcing & Health Expenditures \\
\hline DEM & $-0.86(0.55)$ & $-0.40(1.02)$ & $1.12(1.27)$ & $-0.11(1.16)$ & $-0.35(0.46)$ & $-.69(1.19)$ \\
PDT & $0.15(0.66)$ & $0.40(1.21)$ & $1.43(1.50)$ & $-0.20(1.33)$ & $-0.23(0.54)$ & $-2.84^{*}(1.40)$ \\
PMDB & $-0.02(0.39)$ & $-0.30(0.71)$ & $0.32(0.88)$ & $0.50(0.79)$ & $-0.45(0.33)$ & $-0.07(0.84)$ \\
PP & $0.21(0.54)$ & $0.34(0.97)$ & $-0.81(1.24)$ & $-1.57(1.10)$ & $-1.00^{*}(0.45)$ & $-0.48(1.16)$ \\
PPS & $-0.16(1.03)$ & $1.51(1.84)$ & $-0.72(2.27)$ & $1.60(2.10)$ & $0.58(.84)$ & $-0.29(2.20)$ \\
PR & $0.26(0.62)$ & $-1.28(1.11)$ & $-2.45(1.38)$ & $0.90(1.23)$ & $0.06(0.52)$ & $1.73(1.35)$ \\
PSB & $0.024(0.68)$ & $0.80(1.31)$ & $0.49(1.45)$ & $0.02(1.30)$ & $0.55^{*}(0.57)$ & $1.05(1.47)$ \\
PSDB & $-0.25(0.46)$ & $-1.67^{*}(0.81)$ & $-2.12^{*}(1.03)$ & $-0.67(0.96)$ & $0.21(0.38)$ & $2.02^{*}(0.99)$ \\
PT & $0.40(0.52)$ & $0.09(0.92)$ & $3.51^{* *}(1.14)$ & $0.32(1.01)$ & $1.21^{* *}(0.44)$ & $0.11(1.13)$ \\
PTB & $0.24(0.60)$ & $0.51(1.17)$ & $-0.77(1.40)$ & $-0.78(1.25)$ & $-0.58(0.51)$ & $-0.52(1.30)$ \\
F statistic & 40.28 & 71.60 & $209.84^{*}$ & 43.86 & $191.80^{*}$ & 114.11 \\
Num. obs. & 4650 & 3075 & 2429 & 2987 & 4347 & 4476 \\
\hline
\end{tabular}

$\mathrm{a}^{* * *} p<0.001,{ }^{* *} p<0.01,{ }^{*} p<0.05, p<0.1$. Entries are deviations from the mean (standard errors) times 100

public access to hospital facilities as a means to hold onto office. Alternatively, it could suggest that incumbents hold onto office because they offered greater access to hospital facilities for those who lack access to private care.
Overall, municipal level development (HDI), socioeconomic characteristics, and baseline private sector involvement explained most of the variation seen in private sector health care management and health expenditures. Baseline levels of private sector

Table 3 Covariates in linear regression models predicting 2012 Levels of Privatization by Party in Power in Brazilian Municipalities ${ }^{a}$

\begin{tabular}{|c|c|c|c|c|c|c|}
\hline & Dental & $\mathrm{X}$-rays & Ultrasounds & Hospital Beds & Outsourcing & Health Expenditures \\
\hline \multirow[t]{2}{*}{ Incumbency } & 0.17 & -0.07 & 0.43 & $-1.90^{*}$ & -0.46 & 0.75 \\
\hline & $(0.37)$ & $(0.66)$ & $(0.82)$ & $(0.74)$ & $(0.30)$ & $(0.83)$ \\
\hline \multirow[t]{2}{*}{$\mathrm{HDI}$} & $0.50^{* * *}$ & $0.44^{* * *}$ & $0.27^{*}$ & 0.11 & $0.21^{* * *}$ & $0.31^{*}$ \\
\hline & $(0.06)$ & $(0.11)$ & $(0.13)$ & $(0.12)$ & $(0.05)$ & $(0.10)$ \\
\hline \multirow[t]{2}{*}{ Upper middle class income } & $0.05^{* * *}$ & $0.04^{* *}$ & $0.07^{* *}$ & $0.05^{\circ}$ & -0.01 & $0.08^{* *}$ \\
\hline & $(0.01)$ & $(0.02)$ & $(0.03)$ & $(0.03)$ & $(0.01)$ & $(0.03)$ \\
\hline \multicolumn{7}{|l|}{ Controls for Baseline and Aggregate Change ${ }^{b}$} \\
\hline \multirow[t]{2}{*}{ Total Equipment per capita end of term } & $2.40^{* * *}$ & $4.29^{* * *}$ & $3.45^{* * *}$ & $0.35^{* * *}$ & & \\
\hline & $(0.08)$ & $(0.28)$ & $(0.50)$ & $(0.05)$ & & \\
\hline \multirow[t]{2}{*}{ Total Equipment per capita baseline } & $-2.91^{* * *}$ & $-4.32^{* * *}$ & $-3.38^{* * *}$ & $-0.30^{* * *}$ & & \\
\hline & $(0.09)$ & $(0.29)$ & $(0.43)$ & $(0.04)$ & & \\
\hline$\%$ Private Equipment baseline & $0.83^{* * *}$ & $0.79^{* * *}$ & $0.77^{* * *}$ & $0.75^{* * *}$ & & \\
\hline \multirow[t]{2}{*}{ Interquartile Range } & 0.19 & 0.68 & 0.72 & 0.37 & & \\
\hline & $(0.01)$ & $(0.01)$ & $(0.01)$ & $(0.01)$ & & \\
\hline \multirow[t]{2}{*}{ Outsourcing/Health Expenditures } & & & & & $0.63^{* * *}$ & \\
\hline & & & & & $(0.01)$ & \\
\hline \multirow[t]{2}{*}{ Health Expenditures per capita } & & & & & & $0.77^{* * *}$ \\
\hline & & & & & & $(0.01)$ \\
\hline$R^{2}$ Full Model & 0.76 & 0.76 & 0.73 & 0.67 & 0.44 & 0.69 \\
\hline$R^{2}$ Political Variables Only & 0.01 & 0.01 & 0.02 & 0.01 & 0.01 & 0.01 \\
\hline Num. obs. & 4650 & 3075 & 2429 & 2987 & 4347 & 4476 \\
\hline
\end{tabular}

$\mathrm{a}^{* * *} p<0.001,{ }^{* *} p<0.01,{ }^{*} p<0.05, p<0.1$. Entries are regression coefficients (standard errors). Note: Incumbency estimates multiplied by 100 bestimates for total equipment per capita at end of term and baseline should be considered together. When combined, their sum equals the effect size for the change in the total stock of equipment over the mayoral term 
Table 4 Difference in 2008 \% privatization and health care expenditures by party elected in 2004 (controlling for incumbency, baseline privatization, $\mathrm{HDI}$, and upper middle-class income) $)^{\mathrm{a}, \mathrm{b}}$

\begin{tabular}{|c|c|c|c|c|c|c|}
\hline & Dental & $\mathrm{X}$-rays & Ultrasounds & Hospital Beds & Outsourcing & Health Expenditures \\
\hline \multicolumn{7}{|c|}{ Party Elected In 2004} \\
\hline \multirow[t]{2}{*}{ DEM } & -0.78 & $1.81^{\circ}$ & 2.45 & -0.35 & -0.41 & -0.94 \\
\hline & $(0.54)$ & $(1.07)$ & $(1.26)$ & $(0.96)$ & $(0.36)$ & $(1.18)$ \\
\hline \multirow[t]{2}{*}{ PDT } & -0.17 & -0.59 & -0.72 & 0.87 & $1.38^{* *}$ & 2.04 \\
\hline & $(0.69)$ & $(1.43)$ & $(1.82)$ & (1.34) & $(0.53)$ & $(1.72)$ \\
\hline \multirow[t]{2}{*}{ PMDB } & $-1.31^{* *}$ & -0.13 & 0.06 & 1.21 & 0.02 & 0.57 \\
\hline & $(0.44)$ & $(0.90)$ & $(1.17)$ & $(0.83)$ & $(0.32)$ & $(1.04)$ \\
\hline \multirow[t]{2}{*}{ PP } & -0.86 & -2.07 & -2.40 & $-3.14^{* *}$ & -0.38 & 1.89 \\
\hline & $(0.56)$ & $(1.16)$ & $(1.48)$ & $(1.09)$ & $(0.41)$ & $(1.34)$ \\
\hline \multirow[t]{2}{*}{ PPS } & -0.24 & -0.39 & -1.03 & -1.62 & 1.06 & -1.48 \\
\hline & $(0.75)$ & $(1.49)$ & $(1.84)$ & $(1.37)$ & $(.56)$ & $(1.84)$ \\
\hline \multirow[t]{2}{*}{$P R$} & 0.12 & 1.99 & 0.75 & 1.61 & -0.64 & -1.36 \\
\hline & $(0.71)$ & $(1.42)$ & $(1.69)$ & $(1.28)$ & $(0.49)$ & $(1.60)$ \\
\hline \multirow[t]{2}{*}{ PSB } & 1.06 & 0.50 & 1.90 & 2.08 & $-0.21^{\circ}$ & -0.54 \\
\hline & $(1.19)$ & $(2.31)$ & $(2.52)$ & $(1.73)$ & $(0.70)$ & $(2.31)$ \\
\hline \multirow[t]{2}{*}{ PSDB } & 0.50 & -1.12 & -1.22 & 0.53 & -0.27 & -1.42 \\
\hline & $(0.48)$ & $(1.00)$ & (1.18) & $(0.91)$ & $(0.35)$ & $(1.13)$ \\
\hline \multirow[t]{2}{*}{ PT } & 1.00 & 2.01 & -0.13 & 0.16 & 0.39 & -1.71 \\
\hline & $(0.61)$ & $(1.23)$ & (1.49) & $(1.15)$ & $(0.46)$ & $(1.52)$ \\
\hline \multirow[t]{2}{*}{ PTB } & 0.68 & -1.93 & 0.48 & -1.34 & $-0.93^{*}$ & 2.94 \\
\hline & $(0.66)$ & $(1.36)$ & $(1.65)$ & $(1.28)$ & $(0.47)$ & $(1.54)$ \\
\hline F statistic & $201.65^{*}$ & 151.47 & 93.81 & $176.11^{\circ}$ & 187.60 & 125.74 \\
\hline Num. obs. & 3420 & 2840 & 1988 & 2998 & 4480 & 4534 \\
\hline
\end{tabular}

$\mathrm{a}^{* * *} p<0.001,{ }^{* *} p<0.01,{ }^{*} p<0.05, p<0.1$. Entries are deviations from the mean (standard errors) times 100

${ }^{b}$ Due to limitations in data availability, 2005 baseline values were used for x-rays, ultrasounds, and hospital beds, 2006 values for dental equipment,

and 2004 values for outsourcing and health expenditures

involvement, existing health equipment per capita, and HDI were the strongest predictors of level of health care privatization (Tables 3 and 5). Moreover, R-squared values for predictor-only models including party of the mayor elected and incumbency dramatically increased (from 0.01 to 0.77 in the case of Dental Equipment) with the addition of covariates. This confirmed that, relative to the effects of local supply and demand factors, political party in power explained very little of the mix of private sector health care contracting across Brazilian municipalities.

Consistently, higher Baseline Level of Private Sector Involvement was positively and significantly associated with private sector management for dental equipment, $x$-rays, ultrasounds, and hospitals beds at the end of the electoral term. The 0.83 parameter estimate for this variable in the dental equipment model, means that a difference in privately managed dental equipment of $10 \%$ in 2008 is associated with an $8.3 \%$ greater proportion of privately management dental equipment in 2012 (Table 3). Estimates of percent privately managed equipment for the four equipment outcomes ranges from .75 to .83 . Thus a strong relationship exists between high levels of existing private sector contracting and greater levels of future private sector health contracts. Although this model cannot prove direction of causality, these findings suggest a strong role of path dependence. In other words, constraints of existing institutional arrangements on the set of future possible arrangements determines which municipalities opt for privately managed health care services versus publicly managed.

Also significant is that existing levels of total equipment, at baseline, is consistently negatively associated with private management levels for all types of medical equipment. This association suggests that municipalities that started with lower levels of equipment per capita have a stronger association with private-sector contracting. Thus, a deficit of health care equipment may put pressure on municipalities to seek privately managed equipment to fill the gap. HDI and upper middle class income have slight, but, statistically significant effects on 
Table 5 Results of linear regression models predicting 2008 Levels of Privatization by Party in Power in Brazilian Municipalities ${ }^{a}$

\begin{tabular}{|c|c|c|c|c|c|c|}
\hline & Dental & $X$-rays & Ultrasounds & Hospital Beds & Outsourcing & Health Expenditures \\
\hline \multirow[t]{2}{*}{ Incumbency } & -0.27 & -0.35 & 0.85 & -0.85 & -0.46 & 0.02 \\
\hline & $(0.42)$ & $(0.86)$ & $(1.10)$ & $(0.01)$ & $(0.00)$ & $(0.01)$ \\
\hline \multirow[t]{2}{*}{$\mathrm{HDI}$} & $0.19^{* *}$ & 0.23 & $0.62^{* * *}$ & -0.07 & $0.16^{* * *}$ & $0.79^{* * *}$ \\
\hline & $(0.06)$ & $(0.13)$ & $(0.15)$ & $(0.12)$ & $(0.04)$ & $(0.14)$ \\
\hline \multirow[t]{2}{*}{ Upper middle class income } & $0.09^{* * *}$ & $0.08^{* *}$ & 0.06 & $0.06^{*}$ & $0.04^{* * *}$ & $-0.16^{* * *}$ \\
\hline & $(0.01)$ & $(0.03)$ & $(0.04)$ & $(0.03)$ & $(0.01)$ & $(0.04)$ \\
\hline \multicolumn{7}{|l|}{ Controls for Baseline and Aggregate Change ${ }^{c}$} \\
\hline \multirow[t]{2}{*}{ Total Equipment per capita end of term } & $0.92^{* * *}$ & $4.89^{* * *}$ & $8.85^{* * *}$ & $0.13^{* * *}$ & & \\
\hline & $(0.11)$ & $(0.30)$ & $(0.87)$ & $(0.03)$ & & \\
\hline \multirow[t]{2}{*}{ Total Equipment per capita baseline } & $-0.78^{* * *}$ & $-4.73^{* * *}$ & $-10.37^{* * *}$ & $-0.07^{*}$ & & \\
\hline & $(0.11)$ & $(0.29)$ & $(0.85)$ & $(0.03)$ & & \\
\hline$\%$ Private Equipment & $0.78^{* * *}$ & $0.77^{* * *}$ & $0.72^{* * *}$ & $0.80^{* * *}$ & & \\
\hline \multirow[t]{2}{*}{ Interquartile Range } & 0.20 & 0.67 & 0.73 & 0.47 & & \\
\hline & $(0.01)$ & $(0.01)$ & $(0.01)$ & $(0.01)$ & & \\
\hline \multirow[t]{2}{*}{ Outsourcing/Health Expenditures } & & & & & $0.44^{* * *}$ & \\
\hline & & & & & $(0.01)$ & \\
\hline \multirow[t]{2}{*}{ Health Expenditures per capita } & & & & & & $0.70^{* * *}$ \\
\hline & & & & & & $(0.01)$ \\
\hline $\mathrm{R}^{2}$ Full model & 0.77 & 0.70 & 0.70 & 0.71 & 0.47 & 0.60 \\
\hline$R^{2}$ Political variables only & 0.02 & 0.01 & 0.01 & 0.01 & 0.03 & 0.01 \\
\hline Num. obs. & 3420 & 2840 & 1988 & 2998 & 4480 & 4534 \\
\hline
\end{tabular}

$\mathrm{a}^{* * *} p<0.001,{ }^{* *} p<0.01,{ }^{*} p<0.05, p<0.1$. Entries are regression coefficients (standard errors). Note: Incumbency estimates are multiplied by 100 ${ }^{b}$ Due to limitations in data availability, 2005 baseline values were used for x-rays, ultrasounds, and hospital beds, 2006 values for dental equipment, and 2004 values for outsourcing and health expenditures

${ }^{c}$ Estimates for total equipment per capita at end of term and baseline should be considered together. When combined, their sum equals the effect size for the change in the total stock of equipment over the mayoral term

greater percent private sector management for most of the response variables. The positive direction of this relationship is consistent with the logic that greater levels of development and urbanization in a municipality and higher income levels are associated with a greater demand for health care services, both public and private.

\section{Discussion}

It is not entirely surprising that Brazilian parties show ideologically inconsistent behavior in health system funding and administration in the current policy context in Brazil. First, the relative low magnitude of change across election years also suggests that existing federal policies constrain the latitude that any given mayoral administration or city council has to significantly change municipal budgets. Embedded in the design of the decentralized SUS is a formula based system of financing that renders many municipalities financially dependent on federal- and state- level transfers in order to finance and run their local health systems [1]. These financial transfers are based on population and revenue. Therefore, poorer municipalities have less flexibility in whether or not to contract with private health equipment providers. Municipalities are also constrained in their budgetary expenditures by the 2000 Lei de Responsibilidade Fiscal (Law of Fiscal Responsibility). This law does not allow municipalities to run deficits. Additionally, there are specific requirements for budget allocations to local activities. Thus, the finding that a municipality's material conditions-such as HDI and existing health equipment stock-are stronger predictors of percent privately managed health services likely reflects that economic and regulatory constraints considerably limit the autonomy of any mayoral administration to alter the existing public-private composition of the health system. Under these circumstances, even an administration that wanted to move away from the private sector may lack feasible alternatives.

Second, the lack of distinct health care contracting associations by political party is in line with the literature describing the predominance of clientelism, or patronage-driven political behavior, in Brazilian politics. This would appear to explain why the existing healthcare contracting environment is the single largest and most significant association between contracts at the beginning and end of a given administration. It is 
particularly striking that this does not only hold when incumbents hold onto power, but even when party-inpower changes. Given that contracts are up for reconsideration and renewal annually, this finding suggests a considerable degree of stickiness of the status quo of Brazilian health care contracting in municipalities.

In addition, the contractual landscape that dominates a municipality can generate powerful incentives to maintain the status quo, even for leftist politicians. For example, the association of the PT with greater privatization suggests that political parties who claim to be further to the left but who govern in relatively wealthy municipalities may concede to the pragmatism of contracting with private providers. Although we cannot claim causality, this finding overlaps with accounts that the PT, for example, has moderated its positions over time, departing from its radical, grassroots past [50]. The high demand for medical devices in Brazilian health care is key in this story. With the increasing role of medical technology in health care, and the growing prevalence of chronic diseases in Brazil's population of over 200 million, local governments must meet these demands by drawing on public and private sector resources $[10,46]$. Although mayors have the power to cancel contracts during annual reevaluations, this often does not occur due to lack of other alternatives. The gap between supply and demand in services like imaging, dental care and others certainly lends itself to the political pragmatism suggested by our study results.

No major Brazilian political party exhibits stubborn defiance to granting the private sector a growing role in the SUS or keeping it complementary as Article 199 of the Brazilian constitution outlines [51]. Perhaps one reason for this is that contracting is not seen as interfering with access, so long as SUS patients are able to access private technologies. The one indicator of access to the system by the poor (SUS only patients) that we analyze, hospital beds, appears to be moving in the direction of greater public access.

\section{Study limitations}

One limitation of this study lies in its inability to estimate the effect of more than one political party in power, given that multi-party coalitions govern a substantial percentage of Brazilian municipalities. Ideally, we would be able to gauge the party affiliation of the Secretary of Health, who is chosen by a member of the ruling party. Such a measure might reflect an average ideological score across the members of the governing party, but this average ideology may not better approximate which party chooses the secretary of health. Overall, the Executive retains considerable policymaking power in Brazilian cities, particularly through the Secretariat of Health. Therefore, using mayor's party as an indicator of the parties-in-power remains a logical choice for the political variable.

We are also limited by the absence of data on the role of municipal level health councils. Health councils serve as a conduit for civil society involvement in the health policy process as specified in the 1990 Health Statute (or Lei Orgânica da Saúde). Given the limited choice that citizens appear to have at the ballot box to vote on their preferences for private sector involvement in the SUS, these vehicles for participatory policy making seem all the more crucial for local health care policy making. However, detailed data on the positions of these councils was not available for this study [52].

\section{Conclusions}

In Brazil, where left-leaning politicians make frequent claims to preserve the public nature and accessibility of the health care system, municipal governments were not associated with significant partisan behavior in private sector contracting in health care between 2004 and 2012. Despite political campaign rhetoric, existing institutional arrangements at the national and local level appeared to drive future municipal level public-private contracts. As the level of private sector contracting in health care increases, party ideology appears less important than other factors in determining whether local health system equipment needs are addressed through the private sector. Under rules set by the government itself, the private sector seems poised to eclipse the public sector in some domains of health care delivery. National policy constraints and the entrenchment of public-private contracting suggests that, without a radical departure from current practices, we should expect privatization within the SUS to continue well into the future. In the Brazilian SUS, where social participation in the policy process is of paramount importance, strengthening bodies such as municipal health councils may better enfranchise citizens in the fundamental debate over public and private roles in the health care sector.

\section{Endnotes}

${ }^{1}$ According to a 2012 analysis by the Center of Public Policies of Insper (Instituto de Ensino e Pesquisa) entitled "O Panorama da Saúde do Brasil," (The Health Panorama in Brazil) $87 \%$ of the poorest quintile of the Brazilian population used a public establishment (with $86 \%$ using a SUS establishment) in their last visit, compared to only $23 \%$ of the richest Brazilians (20\% using the SUS) [53].

${ }^{2}$ Throughout this paper, we use the concepts privatization, private sector involvement in the health system, and privately managed health care/services almost interchangeably. However, it should be noted that 
"privatization" is the broadest concept, which includes "private sector involvement in the health system," and "privately managed health services" is, in turn, one type of private sector involvement.

${ }^{3}$ The widespread availability of dental equipment is in part due to the 2004 implementation of the Brasil Sorridente (Brazil Smiling) program, the current National Dental Health Policy initiated to improve dental health in Brazil.

${ }^{4}$ Recent figures show that the dental equipment sector is the most successful of all Brazilian medical device manufacturers. Although Brazil is the largest medical equipment market in Latin America, the majority of medical technology is imported. However, the dental equipment sector is the only device manufacturer that has seen a foreign trade surplus [54].

${ }^{5}$ During the 2012 mayoral elections in São Paulo, the PT candidate Fernando Haddad accused the PSDB Candidate José Serra of having privatization "running through his veins" and of intending to privatize $25 \%$ of SUS beds [28].

\section{Abbreviations}

CNES: Cadastro Nacional de Estabelecimentos de SaúdeNational Registry of Health Establishments; DEM: Democrats Party; HDI: Human Development Index; HMOs: Health Mainenance Organizations; INAMPS: Instituto Nacional de Assistência Médica da Previdência Social, National Institute of Medical Social Security Assistance; MRI: Magnetic Resonance Imaging machine; PDT: Democratic Labor Party; PMDB: Party of the Brazilian Democratic Movement; PP: Progressive Party; PPS: Popular Socialist Party; PR: Party of the Republic; PRB: Brazilian Republican Party; PSB: Brazilian Socialist Party; PSDB: Party of Brazilian Social Democracy; PSOL: Socialism and Freedom Party; PT: Worker's Party; PTB: Brazilian Labor Party; SIOPS: Sistema de Informações Sobre Orçamentos Públicos em Saúde, or Information System on Public Health Budgets; SUS: Sistema Único de Saúde, Unified Health System: TSE: Tribunal Superior Eleitoral, the Supreme Electoral Court

\section{Acknowledgements}

We would like to thank Drs. Frances Hagopian and Meredith Rosenthal for their support in conceptualizing this study, as well as Dr. Elaine Angelino for her feedback on data visualization.

\section{Funding}

The David Rockefeller Center for Latin American Studies at Harvard University provided support for exploratory field research conducted to conceptualize the research question and to locate appropriate datasets. The Princeton Brazil Global Fellows Program provided support during the writing process. The Tufts University Faculty Research Awards Committee helped cover open access publication fees.

\section{Availability of data and materials}

The datasets analyzed in the current study are publicly available in the following data repositories.

- Cadastro Nacional de Estabelecimentos de Saúde (CNES), or National Registry of Health Establishments, maintained by the Brazilian Ministry of Health. http://datasus.saude.gov.br/

- Sistema de Informações Sobre Orçamentos Públicos em Saúde (SIOPS), or Information System on Public Health Budgets database, provided by the Ministry of Health. http://siops.datasus.gov.br

- Tribunal Superior Eleitoral (TSE), the Supreme Electoral Court, a public official database on local and national elections in Brazil. Accessible through: http://www.ipea.gov.br/portal/

- 2010 Brazilian Census. http://censo2010.ibge.gov.br/

\section{Authors' contributions}

AJM led the conceptualization, modeling, data analysis, interpretation of findings, and writing and revising of the article. CES contributed to the conceptualization, interpretation of findings, writing and revisions. AMZ contributed to the overall methodology, modeling and data analysis process. RJB contributed to the conceptualization, research questions, modeling and interpretation of findings. All authors read and approved of the final manuscript.

Ethics approval and consent to participate

Not applicable.

\section{Consent for publication}

Not applicable.

\section{Competing interests}

The authors declare that they have no competing interests.

\section{Publisher's Note}

Springer Nature remains neutral with regard to jurisdictional claims in published maps and institutional affiliations.

\section{Author details}

${ }^{1}$ Department of Community Health, Tufts University, 574 Boston Ave, Suite 208, Medford, MA 02155, USA. ${ }^{2}$ Community Development and Planning, University of Massachusetts, Wheatley Hall, 4th Floor, 144-16, Boston, MA 02125, USA. ${ }^{3}$ Health Care Policy, Harvard Medical School, 180 Longwood Avenue, Boston, MA 02115-5899, USA. ${ }^{4}$ Department of Health Policy and Management, Harvard School of Public Health, 677 Huntington Ave, Boston, MA 02115, USA.

Received: 11 July 2016 Accepted: 3 July 2017

Published online: 12 July 2017

\section{References}

1. Marques E, Arretche M. Condicionantes Locais da Descentralização das Polítics de Saúde. Caderno CRH. 2004;16:55-81.

2. Alves JA. (un?)healthy politics: the political determinants of subnational health Systems in Brazil. Latin Am Pol Soc. 2015;57:119-42. doi:10.1111/j. 1548-2456.2015.00292.x

3. Kuhn DM. Health care reform in Mexico and Brazil: the politics of institutions, spending, and performance. Doctoral dissertation. Cambridge: Harvard University; 2012.

4. Mills A. To contract or not to contract? Issues for low and middle income countries. Health Policy Plan. 1998;13:32-40. doi:10.1093/heapol/13.1.32.

5. Fleury S, Ouverney ALM, Kronemberger TS, Zani FB. Governança local no sistema descentralizado de saúde no Brasil. Rev Panam Salud Publica. 2010; 28: 446-455.

6. Rodrigues PH. Political challenges facing the consolidation of the Sistema Único de Saúde: a historical approach. História, Ciências, Saúde-Manguinhos. 2014:21:37-60. doi:10.1590/S0104-59702014000100003.

7. Matos CA de, Pompeu JC. Where are the contracts? Analysis of the relation between private health services suppliers and the SUS. Ciência \&amp; Saúde Coletiva 2003:8:629-643. doi:10.1590/S1413-81232003000200023.

8. $\quad$ Mendes Á. The long battle for SUS funding. Saúde E Sociedade. 2013;22: 987-93. doi:10.1590/S0104-12902013000400002.

9. Corporación Latinobarómetro. Latinobarómetro - round 20112011. http://www.latinobarometro.org/. (Accessed 19 Feb 2014).

10. Gragnolati M, Lindelow M, Couttolenc B. Twenty Years of Health System Reform in Brazil. The World Bank. 2013.

11. Ministerio da Saúde do Brasil. Cadastro Nacional de Estabelecimentos de Saúde (CNES) n.d. http://datasus.saude.gov.br/. (Accessed 30 June 2017).

12. Gerschman S. Public and private health Insurance in Brazil and European Union Countries. Am J Public Health Res. 2013;1:78-85. doi:10.12691/ajphr-1-4-1.

13. Forgia GML, Harding A. Public-private partnerships and public hospital performance in São Paulo, Brazil. Health Aff. 2009;28:1114-26. doi:10.1377/hlthaff.28.4.1114.

14. Banta HD. Medical technology and developing countries: the case of Brazil. Int J Health Serv. 1986;16:363-73.

15. Arretche M. Toward a unified and more equitable system: health reform in Brazil. Crucial needs, weak incentives: the politics of health and education 
reform in Latin America. Washington, D.C: Woodrow Wilson Center Press/ Johns Hopkins University Press; 2004. p. 155-88.

16. Paim J, Travassos C, Almeida C, Bahia L, Macinko J. The Brazilian health system: history, advances, and challenges. Lancet. 2011;377:1778-97. doi:10. 1016/50140-6736(11)60054-8.

17. Agência Nacional de Saúde Suplementar. Agência Nacional de Saúde Suplementar 2014. http://www.ans.gov.br/. (Accessed 19 Feb 2014).

18. Malta DC, Stopa SR, Pereira CA, Szwarcwald CL, Oliveira M, Reis AC dos, et al. Private health care coverage in the Brazilian population, according to the 2013 Brazilian National Health Survey. Ciência and Saúde Coletiva 2017; 22:179-190. doi:10.1590/1413-81232017221.16782015.

19. Instituto Brasileiro de Geografia e Estatística. Pesquisa Nacional por Amostra de Domicilio, 2001-2011 2011. http://www.ibge.gov.br/. (Accessed 19 Feb 2014).

20. Harvey D. A brief history of Neoliberalism. Oxford: Oxford University Press; 2007.

21. Navarro V. Neoliberalism as a class ideology; or, the political causes of the growth of inequalities. Int J Health Serv. 2007;37:47-62.

22. Homedes $\mathrm{N}$, Ugalde A. Why neoliberal health reforms have failed in Latin America. Health Policy. 2005;71:83-96. doi:10.1016/.j.healthpol.2004.01.011.

23. Mooney G. Neoliberalism is bad for our health. Int J Health Serv. 2012;42: 383-401.

24. Muntaner C, Salazar RMG, Benach J, Armada F. Venezuela's barrio Adentro: an alternative to neoliberalism in health care. Int J Health Serv. 2006;36:803-11.

25. De Vos P, Van der Stuyft P. Sociopolitical determinants of international health policy. Int J Health Serv. 2015:45:363-77. doi:10.1177/ 0020731414568514.

26. Feo O, Siqueira CE. An alternative to the neoliberal model in health: the case of Venezuela. Int J Health Serv. 2004;34:365-75. doi:10.2190/NHFKGHQW-AQLA-YC5D.

27. Palmer $\mathrm{N}$. The use of private-sector contracts for primary health care : theory, evidence and lessons for low-income countries. Bull World Health Organ. 2000;78:821-9.

28. Cardoso D. Haddad diz que privatização "corre na veia" de Serra - Política. Estadão. 2012.

29. Fleury S. Brazil's health-care reform: social movements and civil society. Lancet. 2011;377:1724-5. doi:10.1016/S0140-6736(11)60318-8.

30. Borges FT, Moimaz SAS, Siqueira CE, Garbin CAS. Anatomia da privatização neoliberal do Sistema Único de Saúde: O Papel das Organizações Sociais de Saúde. Cultura Academica: Sao Paulo; 2012.

31. Soares GB, Borges FT, Reis dos Santos R, CAS G, SAS M, Siqueira CE. Organizações Sociais de Saúde (OSS): Privatização da Gestão de Serviços de Saúde ou Solução Gerencial para of SUS? Rev Gest Saúde (Brasília). 2016;7:828-50

32. Ferraz MB, Miranda IC, Padovan J, Coelho de Soárez P, Ciconelli R. Health care costs in the last four years of life for private health plan beneficiaries in Brazil. Rev Panam Salud Publica. 2008:24:120-6.

33. Tribunal Superior Eleitoral. Partidos políticos registrados no TSE 2014 http://www.tse.jus.br/partidos/partidos-politicos. (Accessed 21 Feb 2014).

34. Weyland K. Social movements and the state: the politics of health reform in Brazil. World Dev. 1995;23:1699-712. doi:10.1016/0305-750X(95)00079-R.

35. Nichter S. Electoral Clientelism or relational Clientelism? Healthcare and sterilization in Brazil. Social Science Research Network: Rochester, NY; 2011.

36. Stokes S. Political Clientelism. Oxford University Press Handbook of Comparative Politics; 2007. p. 604-27.

37. Mainwaring S. Rethinking Party Systems in the Third Wave of democratization: the case of Brazil. 1st ed. Stanford, Calif: Stanford University Press; 1999.

38. Ames B. The deadlock of democracy in Brazil. Ann Arbor: University of Michigan Press; 2002.

39. Epstein DJ. Clientelism versus ideology problems of party development in Brazil. Party Polit. 2009;15:335-55. doi:10.1177/1354068809102250.

40. Hagopian F, Gervasoni C, Moraes JA. From patronage to program the emergence of party-oriented legislators in Brazil. Comparative Political Studies. 2009:42:360-91. doi:10.1177/0010414008325572.

41. Power TJ, Zucco C Jr. Estimating ideology of Brazilian legislative parties, 1990-2005: a research communication. Lat Am Res Rev. 2009;44:218-46. doi: 10.1353/lar.0.0072.

42. Zucco C Jr, Lauderdale BE. Distinguishing between influences on Brazilian legislative behavior. Legis Stud Q. 2011;36:363-96. doi:10.1111/j.1939-9162. 2011.00019.x.
43. Hagopian F, Power TJ. Politics in Brazil. Comparative politics today: a world view: international edition. Tenth ed. New York: Pearson Longman; 2012 p. 470-519.

44. Pierson P. Increasing returns, path dependence, and the study of politics. Am Polit Sci Rev. 2000;94:251-67. doi:10.2307/2586011.

45. Pierson P. Politics in time: history, institutions, and social analysis. First edition edition. Princeton University Press: Princeton; 2004.

46. Forgia GML, Couttolenc B. Hospital performance in Brazil: the search for excellence. World Bank Publications; 2008.

47. Ministério da Saúde. SIOPS. Portal Da Saúde - Ministério Da Saúde - Www. saude.gov.br n.d. http://portalsaude.saude.gov.br/index.php/o-ministerio/ principal/siops. (Accessed 29 June 2017).

48. Tribunal Superior Eleitoral. Repositório de dados eleitorais n.d. http://www tse.jus.br/eleicoes/estatisticas/repositorio-de-dados-eleitorais. (Accessed 29 June 2017).

49. Paim JS. The citizen constitution and the 25th anniversary of the Brazilian unified National Health System (SUS). Cadernos de Saúde Pública. 2013;29: 1927-36. doi:10.1590/0102-311X00099513.

50. Hunter W. The transformation of the workers' Party in Brazil, 1989-2009. New York: Cambridge University Press; 2010.

51. Santos NR dos. The evolution of the Brazilian National Health System, strategic courses of action and strategies to understand these actions. Ciência and Saúde Coletiva 2007;12:429-435. doi:10.1590/S141381232007000200019

52. Avritzer L. Participatory institutions in democratic Brazil. Washington, D.C., Baltimore: Johns Hopkins University Press; 2009.

53. Instituto de Ensino e Pesquisa. O Panorama da Saúde do Brasil. 2012.

54. Broadening healthcare access in Brazil through innovation. The Economist Insights 2010. http://perspectives.eiu.com/healthcare/broadeninghealthcare-access-brazil-through-innovation. (Accessed 16 June 2015).

\section{Submit your next manuscript to BioMed Central and we will help you at every step:}

- We accept pre-submission inquiries

- Our selector tool helps you to find the most relevant journal

- We provide round the clock customer support

- Convenient online submission

- Thorough peer review

- Inclusion in PubMed and all major indexing services

- Maximum visibility for your research

Submit your manuscript at www.biomedcentral.com/submit 